\title{
Studies on Combining Ability through Line $\times$ Tester Analysis in Okra [Abelmoschus esculentus (L.) Moench]
}

\author{
Ayushi Yadav, Krishna Kumar Mishra* and Aneeta Yadav
}

Faculty of Agricultural Sciences and Allied Industries, Rama University, Mandhana, Kanpur (U.P.)-209217, India

*Corresponding author

Key w or d s
$\begin{aligned} & \text { Line } \times \text { Tester, gca, } \\ & \text { sca, analysis of } \\ & \text { variance and okra }\end{aligned}$
Article Info
$\begin{aligned} & \text { Accepted: } \\ & 15 \text { May } 2020 \\ & \text { Available Online: } \\ & \text { 10 June } 2020\end{aligned}$

\section{Introduction}

Okra (Abelmoschus esculentus (L.) Moench) is commonly known as bhindi or lady's finger belonging to family Malavacesae having chromosome no is $2 \mathrm{n}=130,2 \mathrm{n}=8 \mathrm{x}=72$ or 144. Okra is extensively grown in tropical, sub-tropical and warm areas of the world. It is a powerhouse of variable nutrients and because of this okra has a prominent position
The combining ability analysis was estimated from a Line $\times$ Tester crossing programme proposed by Kempthorne in 1957. Total 24 crosses were evaluated from 12 lines and 2 testers. Experiment was conducted at research field of Rama University, Kanpur during year 2019-20 with an aim to evaluate okra hybrids for yield and its attributing traits. Various morphological parameters viz., days to 50\% flowering, plant height $(\mathrm{cm})$, number of branches/plant, length of fruit per plant $(\mathrm{cm})$, diameter of fruit $(\mathrm{cm})$, number of seeds per fruit, number of fruits per plant and edible fruit yield per plant $(\mathrm{g})$ were recorded. Analysis of variance revealed that parents and hybrids differed significantly for most of the traits under study. The gca and sca effects were significantly different for majority of the traits. Estimates of gca effect revealed that Parbhani Kranti, K.S-325 and Pusa Sawni are good general combiners for fruit yield, number of fruits per plant and no. of branches per plant etc. The estimation of sca effects reveled that the cross combition Prabhani kranti x A.B - 1, KS 325 x A. B 2, B. O 2 x A. B 2 and K.S-312 x A.B-2 etc. were observed most promising for fruit yield per plant, fruit length, number of fruit per plant and plant length etc. Thus the parents showing high gca can be utilised in hybridization programme for production of promising recombinants, while the crosses showing high sca for specific characters can be directly used for hybrid development. 
along with their parents (12 lines and 2 testers) for different characters. The experiment was conducted with certain objectives to evaluate the per se performance of parents and their hybrids for some important characters, determining the magnitude of the GCA and SCA variances and their effects, to understand the nature of gene action for yield and its component characters and also to obtain information on the extent of heterosis for prediction of superior hybrid combinations for the traits under study.

\section{Materials and Methods}

The experiment was conducted at Research Farm, Faculty of Agricultural Sciences and Allied Industries, Rama University, Kanpur in the year 2019-20. The genotypes used in the experiment shows geographical as well as morphological diversity, which is the prerequisite for any breeding programme. The experiment material consists of 12 lines and 2 testers, listed in Table 1. Randomized block design was used for experimentation. Hand emasculation and crossing was carried out in a definite fashion as per the requirements of Line $\times$ Tester crossing programme, resulting in 24 hybrid lines. All the 24 hybrids along with 12 lines and 2 testers were evaluated in RBD. The observation were recorded for different traits viz., days to $50 \%$ flowering, plant height $(\mathrm{cm})$, number of branches/plant, length of fruit $(\mathrm{cm})$, diameter of fruit $(\mathrm{cm})$, number of seeds per fruit, number of fruits per plant and edible fruit yield per plant $(\mathrm{g})$. The variances and corresponding standard errors of the mean were computed from the deviations of the individual values (Panse and Sukhatme, 1978). The observed values were subjected to Line $\times$ Tester analysis and the general combining ability effects of parents and specific combining ability effects of different crosses were evaluated by the methods developed by Kempthorne (1957).
Proportional contributions from lines, testers and the interactions to total variance were calculated as per the method proposed by Singh and Choudhary (1985).

\section{Results and Discussion}

Analysis of variance due to parents and hybrids for eight characters are presented in Table 2. ANOVA shows significant difference among hybrids for all the characters except plant height. The combining ability variances were estimated for eight characters. General combining ability effects for all the parents has been presented in Table 3 . The specific combining ability effects are presented in Table 4. The characters under study are denoted as per following:

DFF- days to $50 \%$ flowering, $\mathrm{PH}-$ plant height $(\mathrm{cm})$, NBPP- number of branches per plant, NFP- number of fruits per plant, FLfruit length $(\mathrm{cm})$, DF-fruit diameter $(\mathrm{cm})$, SPF- number of seeds per fruit, EYPP- edible fruit yield per plant (g).

The gca effect was maximum for days to $50 \%$ flowering (3.972***) in case of Pusa Sawani followed by $\left(3.806^{* * *}\right)$ in case of B. O- 2 . For plant height, gca effect was maximum (8.000) in Pusa Sawani followed by Parbhani Kranti (6.667). In case of no. of branches per plant, both Pusa Sawani and Parbhani Kranti showed highest gca values i.e. $(0.792 * *)$. For no. of fruits per plant, fruit length and fruit diameter, gca effect was maximum in case of Pusa Sawani. Although gca effect for no. of seeds per fruit was maximum (5.208***) in case of K.S-325. The gca effect for edible yield per plant was reported maximum $\left(18.153^{* *}\right)$ in case of Parbhani Kranti followed by B. O-2 (13.621*). Thus the genotypes Pusa Sawani, Parbhani Kranti, K. S-325 and B. O-2 can be categorised as good general combiners and may be used as one of the parent in okra hybridization programme. 
The combining ability variance showed higher magnitude of GCA variance in some cases, indicating preponderance of additive gene action, while in some cases SCA variance are high indicating preponderance of non-additive (dominance) gene action.

On the basis of SCA effects, the hybrid Parbhani Kranti $\times$ A. B-1 was found to be most promising for fruit yield per plant on the basis of per se performance followed by K. S$325 \times$ A. B-2. The crosses showing high specific combining ability effects and per se performance for fruit yield per plant suggesting that these hybrids may be exploited in further breeding programme. For fruit length, sca effect was highest in case of B. O-2 $\times$ A. B-2. In case of plant height and no. of branches per plant, the most promising cross was P-7× A. B-1. SCA effect for no. of fruits per plant was observed maximum in A. Abhaya $\times$ A. B-1. The crosses showing high specific combining ability effects and per se performance for corresponding traits suggesting that these hybrids may be exploited in further breeding programme.

Table.1 List of genotypes used in crossing programme

\begin{tabular}{|c|c|c|}
\hline S. No. & \multicolumn{1}{|c|}{ Parents } & \multicolumn{1}{c|}{ Genotypes } \\
\hline & \multicolumn{2}{|c|}{ Lines (females) } \\
\hline $\mathbf{1}$ & L1 & Pusa Sawani \\
\hline $\mathbf{2}$ & L2 & P-7 \\
\hline $\mathbf{3}$ & L3 & K.S- 312 \\
\hline $\mathbf{4}$ & L4 & A-Abhaya \\
\hline $\mathbf{5}$ & L5 & Prabhani Kranti \\
\hline $\mathbf{6}$ & L6 & V.R.O-6 \\
\hline $\mathbf{7}$ & L7 & B.O- 2 \\
\hline $\mathbf{8}$ & L8 & K.S -325 \\
\hline $\mathbf{9}$ & L9 & K.S -326 \\
\hline $\mathbf{1 0}$ & L10 & K.S- 443 \\
\hline $\mathbf{1 1}$ & L11 & K.S- 445 \\
\hline $\mathbf{1 2}$ & L12 & K.S- 447 \\
\hline \multicolumn{3}{|c|}{ Testers (Males) } \\
\hline $\mathbf{1 3}$ & T1 & A.B-1 \\
\hline $\mathbf{1 4}$ & T2 & A.B-2 \\
\hline
\end{tabular}

Table.2 Analysis of variance

\begin{tabular}{|l|l|l|l|l|l|l|l|l|l|}
\hline & DF & DFF & PH(cm) & NBPP & NFP & FL(cm) & DF(cm) & SPF & EYPP(g) \\
\hline Replication & 2 & $28.18^{*}$ & $1179.04 * *$ & 0.17 & 15.79 & $28.08^{* * *}$ & 0.071 & 0.542 & $1105.18^{*}$ \\
\hline Hybrids & 23 & $29.36^{* * *}$ & 268.17 & $1.40^{* * *}$ & $12.46^{* * *}$ & $9.66^{* * *}$ & $2.21^{* * *}$ & $63.740^{* * *}$ & $624.01^{*}$ \\
\hline Line effect & 11 & 39.72 & 346.42 & 1.88 & $19.15^{*}$ & $16.92^{* *}$ & 0.15 & 79.943 & 556.41 \\
\hline Tester effect & 1 & 37.56 & 296.06 & 3.12 & 9.39 & 2.21 & 0.11 & 171.125 & 1870.69 \\
\hline Line x tester & 11 & $18.25^{* *}$ & 187.39 & $0.77^{*}$ & 6.06 & 3.08 & $0.27 * * *$ & $37.792^{*}$ & 578.29 \\
\hline Error & 46 & 6.60 & 166.13 & 0.35 & 3.95 & 2.97 & 0.02 & 16.25 & 321.01 \\
\hline Total & 71 & 14.58 & 227.79 & 0.69 & 7.04 & 5.84 & 0.07 & 31.30 & 444.26 \\
\hline
\end{tabular}

$*$ Significant at $5 \%$ probability level, **Significant at $1 \%$ probability level, *** Significant at $0.1 \%$ probability level 
Table.3 General combining ability (gca) effects of parents for different traits in okra

\begin{tabular}{|c|c|c|c|c|c|c|c|c|}
\hline & DFF & $\mathbf{P H}(\mathrm{cm})$ & NBPP & NFP & FL(cm) & $\mathrm{DF}(\mathrm{cm})$ & SPF & $\operatorname{EYPP}(g)$ \\
\hline Pusa sawani & $3.972 * * *$ & 8.000 & $0.792 * *$ & $2.667 * * *$ & $4.016 * * *$ & $0.293 * * *$ & $4.042 * *$ & 2.347 \\
\hline P-7 & 0.876 & $-10.17^{*}$ & 0.292 & $1.833^{*}$ & 1.174 & -0.132 & $4.708 * *$ & 3.014 \\
\hline K.S 312 & 0.306 & -5.833 & -0.208 & $-2.83 * * *$ & -0.134 & 0.069 & 0.078 & 7.347 \\
\hline A. Abhaya & 1.806 & 6500 & 0.458 & 0.667 & 0.307 & -0.102 & 0.042 & -9.319 \\
\hline Parbhani Kranti & $2.472 * *$ & 6.667 & $0.792 * *$ & 1.167 & $-2.98 * * *$ & -0.092 & $-4.29 * *$ & $18.153 * *$ \\
\hline V.R.O - 6 & -1.528 & $-12.50^{*}$ & 0.125 & $-2.33 * *$ & 0.207 & -0.002 & -2.625 & 3.847 \\
\hline В . O -2 & $3.806 * * *$ & 1.667 & $-0.542 *$ & -0.333 & 0.524 & $-0.247 * *$ & $-2.958^{*}$ & $13.621 *$ \\
\hline K.S-325 & $-3.194 * *$ & 4.500 & -0.208 & $1.667 *$ & 0.209 & 0.044 & $5.208 * * *$ & -7.819 \\
\hline K.S-326 & $-2.194 *$ & 5.167 & $-1.04 * * *$ & 0.833 & -1.059 & 0.129 & -1.292 & -1.986 \\
\hline K.S -443 & $-1 . .194$ & 5.833 & $-0.542 *$ & 0.000 & $-1.634 *$ & $0.204 * *$ & $-5.62 * * *$ & 6.347 \\
\hline K.S - 445 & $-1.861 *$ & 0.500 & -0.208 & -2.000 & -0.338 & 0.009 & -1.292 & -10.319 \\
\hline K.S - 447 & $-3.194 * *$ & $-10.33^{*}$ & 0.292 & $-1.333^{* *}$ & 0.324 & $-0.172^{*}$ & 3.375 & 11.014 \\
\hline A.B - 1 & 0.722 & 2.028 & $0.208^{*}$ & 0.361 & 0.175 & -0.039 & -1.542 & -5.097 \\
\hline A.B -2 & -0.722 & -2.028 & $-0.208^{*}$ & -0.361 & -0.175 & 0.039 & 1.542 & 5.097 \\
\hline CD95\%GCA(LINE) & 1.834 & 8.174 & 0.480 & 1.479 & 1.259 & 0.146 & 2.945 & 12.051 \\
\hline $\begin{array}{l}\text { CD95\%GCA } \\
\text { (TESTER) }\end{array}$ & 0.749 & 3.557 & 0.961 & 0.604 & 0.541 & 0.060 & 1.202 & 4.920 \\
\hline
\end{tabular}

*Significant at $5 \%$ probability level, **Significant at $1 \%$ probability level, *** Significant at $0.1 \%$ probability level

Table.4 Specific combining ability (sca) effects of hybrids for different characters in okra

\begin{tabular}{|c|c|c|c|c|c|c|c|c|}
\hline & DFF & PH $(\mathrm{cm})$ & NBPP & NFP & FL $(\mathbf{c m})$ & $\mathrm{DF}(\mathbf{c m})$ & SPF & EYPP(g) \\
\hline Pusa sawani $x$ A.B - 1 & -0.222 & -4.361 & -0.042 & -0.528 & 0.990 & $0.210^{*}$ & -1.125 & 3.097 \\
\hline Pusa sawani $x$ A.B - 2 & 0.222 & 4.361 & 0.042 & 0.528 & -0.990 & $-0.210^{*}$ & 1.125 & -3.097 \\
\hline P-7x A.B - 1 & 1.611 & $12.472 *$ & $0.792 *$ & -0.361 & -0475 & 0.202 & 1.542 & 1.431 \\
\hline P - 7 X A.B-2 & -1.611 & $-12.472 *$ & $-0.792 *$ & 0.361 & 0.475 & -0.202 & -1.542 & -1.431 \\
\hline K.S 312 x A.B-1 & 1.778 & -2.194 & -0.042 & 1.639 & 0.116 & -0.053 & 0.875 & -2.236 \\
\hline K.S-312x A.B-2 & -1.788 & 2.194 & 0.042 & -1.639 & -0.116 & 0.053 & -0.875 & 2.236 \\
\hline A.Abhaya x A.B-1 & 0.944 & -1.194 & 0.292 & 1.806 & 0.358 & -0.031 & $-4.458 *$ & -0.569 \\
\hline A.Abhaya x A.B-2 & -0.944 & 1.194 & -0.292 & -1.806 & -0.358 & 0.031 & $4.458 *$ & 0.569 \\
\hline Prabhani kranti x A.B-1 & 1.611 & 1.972 & 0.292 & -0.361 & 0.341 & 0.175 & 0.208 & $19.597 *$ \\
\hline Prabhani kranti x A.B-2 & -1.611 & -1.972 & -0.292 & 0.361 & -0.341 & -0.175 & -0.208 & $-19.597 *$ \\
\hline V.R.O-6 x A.B-1 & -1.056 & 0.194 & -0.375 & 0.861 & 0.971 & -0.058 & $5.542 *$ & 1.931 \\
\hline V.R.O-6 x A.B-2 & 1.056 & -0.194 & 0.375 & -0.861 & -0.971 & 0.058 & $-5.542 *$ & -1.931 \\
\hline B.O-2 x A.B-1 & 1.611 & 1.306 & -0.042 & 0.139 & -1.225 & 0.137 & 1.875 & 11.097 \\
\hline B.O-2 x A.B-2 & -1.611 & -1.306 & 0.042 & -0.139 & 1.225 & -0.137 & -1.875 & -11.097 \\
\hline K.S-325 x A.B-1 & 0.278 & -4.194 & 0.292 & 0.139 & -0.492 & $-0.321 * *$ & -0.292 & -16.403 \\
\hline K.S-325 x A.B-2 & -0.278 & 4.194 & -0.292 & -0.139 & 0.492 & $0.321 * *$ & 0.292 & 16.403 \\
\hline K.S-326 x A.B-1 & $-3.72 * *$ & 4.806 & -0.208 & 0.972 & 0.191 & $-0.370 * * *$ & 0.208 & 0.764 \\
\hline K.S-326 x A.B-2 & $3.72 * *$ & -4.806 & 0.208 & -0.972 & -0.191 & $0.370^{* * * *}$ & -0.208 & -0.764 \\
\hline K.S-443 x A.B-1 & -2.056 & 4.472 & -0.375 & -0.528 & -1.217 & $-0.235^{*}$ & -2.125 & -5.236 \\
\hline K.S-443 x A.B-2 & 2.056 & -4.472 & 0.375 & 0.528 & 1.217 & $0.235^{*}$ & 2.125 & 5.236 \\
\hline K.S-445 x A.B-1 & 0.611 & -3.861 & -0.375 & -1.528 & 0.546 & 0.140 & -2.458 & -15.236 \\
\hline K.S-445 x A.B-2 & 0.611 & 3.861 & 0.375 & 1.528 & -0.546 & -0.140 & 2.458 & 15.236 \\
\hline K.S-447 x A.B-1 & -1.389 & -9.028 & -0.208 & -0.528 & 0.075 & 0.202 & 0.208 & 1.764 \\
\hline K.S-447 x A.B-2 & 1.389 & 9.028 & 0.208 & 0.528 & -0.075 & -0.202 & -0.208 & -1.764 \\
\hline CD95\%SCA & 2.593 & 12.323 & 0.679 & 2.092 & 1.781 & 0.206 & 4.165 & 17.043 \\
\hline
\end{tabular}

* Significant at $5 \%$ probability level, **Significant at $1 \%$ probability level, *** Significant at $0.1 \%$ probability level 
The gca and sca effects along with heterosis were estimated for twenty four hybrids along with twelve lines and two testers from a $\mathrm{L} \times \mathrm{T}$ analysis. The gca and sca effects differed significantly for the crosses for all the characters under study except for plant height. As per the estimates of gca effect, genotypes Pusa Sawani, Parbhani Kranti, K.S-325 and B. O-2 were identified as good general combiners and may be used as a parent in hybridization programme in okra. On the basis of SCA effects, the hybrid Parbhani Kranti $\times$ A. B-1 was found to be most promising for fruit yield per plant on the basis of per se performance followed by K. S-325 × A. B-2. The crosses showing high specific combining ability effects and per se performance for fruit yield per plant suggesting that these hybrids may be exploited in further breeding programme.

\section{References}

Ali, H.A., M.H.Z. Eldekashy and A.A. Helay (2013). Combining ability and heterosis studies for yield components in some cultivars of okra (Abelmoschus esculentus L. Moench). American Eurasian. J. agri. Environ. Sci., 13(2): 162-167.

Amaranatha Reddy, M. and O. Sridevi (2018). Combining Ability for Yield and Yield Components through Diallel Analysis in Okra (Abelmoschus esculentus L. Moench). Int. J. Curr. Microbiol. App. Sci., 7(3): 1023-1029.

Annapurna and S.P. Singh (2018). Analysis of combining ability status and nature of $\mathrm{m}$ gene action among hybrids for yield and quality traits in okra (Abelmoschus esculentus L. Moench). Int. J. Pure App. Biosci., 6(2): 1547-1553.

Chaudhary, D.R., Jagmohan Kumar, P. Vidyasagar and S.K. Sharma (1991). Line $\times$ Tester analysis of combining ability of okra. South Indian Hort.,
39(6): 198-204.

Dabhi, K. H., Vachhani, J. H., Poshiya, V. K., Jivani, L. L. and Kacchadia, V. H. (2010). Combining ability for fruit yield and its components over environments in okra (Abelmoschus esculentus (L.) Moench). Res. on Crops, 11(2): 383-90.

Nagesh, G.C., R. Mulge, V. Rathod, L.B. Basavaraj and S.M. Mahaveer (2014). Heterosis and combining ability studies in okra (Abelmoschus esculentus L. Moench) for yield and quality parameters. The Bioscan., 9(4): 17171723.

Pawar, V.Y., Poshiya, V. K. and Dhaduk, H. L.(1999). Heterosis studies in okra (Abelmoschus esculentus (L.) Moench). G.A.U. Res. J., 25(1): 26-31.

Prakash, M., Kumar, M.S., Saravanan, K., Kannan, K. and Ganesan, J. (2002). Line $\mathrm{x}$ Tester analysis in okra. Ann. Agril. Res., 23(2): 233-37.

Reddy, M.T., Kadiyala, H., Mutyala, G., Reddy, K.C., Begum H., Reddy, R.S.K. and Babu J.D. (2012). Genetic analysis for yield and its components in okra (Abelmoschus esculentus (L.) Moench). Songklanakarin J. Sci. Tech., 34 (2): 133-141.

Abinaya, S., K.R. Saravanan, P. Thangavel, R. Madhubala and K.R. Pushpanathan. (2020). Studies and heterosis and combining ability analysis in Okra (abelmoschus esculentus moench.) Plant Archives., 20(I): 1340-1342.

Singh, D.R., Singh, P.K., Syamal, M.M. and Gautam, S.S. (2009). Studies on combining ability in okra. Indian $J$. Hort., 66 (2): 277-80.

Weerasekara, D., Jagadeesha, R.C, Wali, R.C., Shalimath, P.M., Hosamani, R.M. and Kalappanavar, I. K. (2008). Combining ability of yield and yield components in okra (Abelmoschus esculentus (L.) Moench). Karnataka J. Agric. Sci., 21 (2) : 187-89. 


\section{How to cite this article:}

Ayushi Yadav, Krishna Kumar Mishra and Aneeta Yadav. 2020. Studies on Combining Ability through Line $\times$ Tester Analysis in Okra [Abelmoschus esculentus (L.) Moench]. Int.J.Curr.Microbiol.App.Sci. 9(06): 494-499. doi: https://doi.org/10.20546/ijcmas.2020.906.064 